\title{
Comparative Leisure Physical Activity: A Comparison Between Polish and European Population
}

Authors' contribution:

A) conception and design of the study

B) acquisition of data

C) analysis and interpretation of data

D) manuscript preparation

E) obtaining funding

\author{
Elżbieta Biernat $^{1 \text { A-D }}$, Monika Piątkowska ${ }^{2}$ A-D \\ ${ }^{I}$ Warsaw School of Economics, Poland \\ ${ }^{2}$ Josef Pilsudski University of Physical Education in Warsaw, Poland
}

ABSTRACT

Introduction and objective: In Poland, there are only a few studies that refer to the whole society's participation in sport and recreation and that are based an the international questionnaire thus allowing for comparative analysis with other European reports. The aim of the study was to determine the association between leisure physical activity and socio-demographic variables.

Methods: A survey based on CAPI was carried out in Poland from October to November 2012. A random sample of Polish adults $(\mathrm{N}=1,633)$ was interviewed using the IPAQ-long form. The data were analyzed using standard statistical procedures.

Results: More than $21 \%$ of Polish subjects did not undertake any physical activity in their leisure time. Of those who were physically active, over $70 \%$ engaged in vigorous physical activity; only one in four respondents performed moderate physical activity or walking. The average leisure physical activity of the Poles was $1,916.9 \pm 2,621 \mathrm{MET}-\mathrm{min} /$ week. A comparison of the current results and European research findings demonstrated that the median physical activity for the Polish population (MET-min/week) was similar to the median values for Czech subjects and Norwegian males and nearly three times higher than Croats.

Conclusions: Insufficient participation in the conscious process of caring for one's health is a common occurrence among adults living in the EU. In order to encourage the Polish population's participation in physical activities, it is necessary to raise their awareness of the need of well-balanced, regular exercise. Furthermore, this study suggests that caution is warranted before using the CAPI technique to provide the IPAQ-long form survey.

KEYWORDS $\quad$ physical activity, leisure, comparative study, Poland, European population

\section{Introduction}

Research institutions around the world are increasingly engaged in a cross-sectional research on physical activity (European Commission, 2004, 2010; Physical Activity..., 1996; Sidney et al., 1991) and Poland is no exception (Biernat, 2011; Drygas et al., 2005; Polish population..., 2003; Piątkowska, 2012). However, the majority of investigations and analyses conducted by research bodies in Poland (such as academic institutions, the Central Statistical Office, or the Public Opinion Research Centre) have either 
evaluated the frequency and duration of a physical activity by using varied, often non-comparable, methods or have defined an active life style differently. The key aspects of these analyses were the type of activity undertaken in leisure time, the percentage of participation in various activities, the duration of a particular activity, and the frequency of occurrence of a specific activity in a set behavior of a group or an individual (Toczek-Werner \& Sołtysik, 1997). The data were often collected and analyzed as they existed at the time of assessment by using small samples that varied in terms of participants' age, gender, and employment status.

As an answer to the social need for a detailed verification of the existing research findings, there was a call for a broader, more representative set of results. This issue was addressed by raising the idea and the current concept of leisure physical activities diagnosis by means of a Polish version of the Last 7 Days Physical Activity Recall (L7DPAR), which was officially approved by an international IPAQ committee (Biernat et al., 2007; Gajewski \& Biernat, 2010). This analysis, along with the socio-demographic factors gender, age, education, occupation, income, and the size of the place of residence, would allow for creating a complex profile of the investigated population, which in turn would become a valuable reflection of the lifestyle(s) of the Polish population. It is expected that the current investigation will add to the understanding of the differences and similarities between Polish citizens' leisure physical activity and that of other European citizens (both measured with the same tools).

\section{Material and methods}

The surveys were carried out between 10 October 2012 and 14 November $2012^{1}$ via ComputerAssisted Telephone Interviews (CATI). Qualified and supervised surveyors conducted the interviews. They delivered the questions in a way that was equally easy for all respondents to comprehend. Leisure physical activity was estimated by the Polish long version of International Physical Activity Questionnaire (IPAQ) (Biernat, 2013).

The sample consisted of 2,004 Polish people aged 15 years or older. They were selected through the stratified-quota sampling method. The demographic variables of age, sex, education, and place of residence were stratified The quotas, which were established proportionally, were based on the data made accessible to the researchers by Poland's Central Statistical Office. Furthermore, in order to increase the representativeness of the sample, a data weighting procedure of the variables listed above was used. The quotas were proportionally assessed based on the data provided by the Central Statistical Office.

The analysis excluded 234 participants who were over the age of 69 years, as the IPAQ methodology recommends using the questionnaires for the population in the age range of 15-69 years. Of the remaining sample $(\mathrm{n}=1,770), 132$ subjects who reported physical activity exceeding 16 hours per day were excluded from the analysis (Guidelines..., 2005). The characteristics of the respondents can be found in Table 1.

Data analysis was accomplished using statistical software IBM SPSS 21.0. Descriptive statistics was used to present the basic data in the study including the mean, median (me), extreme values (max, min), and standard deviation (SD). Inferential statistics was applied in order to reveal statistically significant differences between groups. It included the $t$-test and the chi-squared test. The significance level was $\mathrm{p}=0.05$.

\section{Results}

The data analysis shows that over $21 \%$ of Polish subjects did not undertake any physical activity (PA) in their leisure time (see Table 2). The lowest physical activity was observed for subjects with secondary education (23.3\%); farmers, gardeners, foresters and fishermen $(30 \%)$; and those with average gross income (per capita in household) of 2,000-2,999 zł per month (26.6\%).

\footnotetext{
${ }^{1}$ Data collection excluded All Saints' Day (a national holiday in Poland) due to the increased physical activity frequently caused by visits to cemeteries.
} 
Table 1. Socio-demographic characteristics of Polish respondents aged 15-69 years

\begin{tabular}{lrr}
\hline Variables & $\mathbf{N}=\mathbf{1 , 6 3 3}$ \\
\hline Sex & $\mathrm{n}$ & $\%$ \\
Male & 801 & 49.1 \\
Female & 832 & 50.9 \\
Age & 88 & 5.4 \\
15-19 years & 206 & 12.6 \\
20-24 years & 200 & 12.2 \\
25-29 years & 322 & 19.7 \\
30-39 years & 295 & 18.1 \\
40-49 years & 293 & 17.9 \\
50-59 years & 229 & 14.0 \\
60-69 years & & \\
Education & 431 & 26.4 \\
Primary & 911 & 55.8 \\
Secondary & 291 & 17.8 \\
Higher & & \\
Place of residence & 451 & 27.6 \\
Village & 222 & 13.6 \\
City up to 20,000 inhabitants & 343 & 21.0 \\
City with 21,000-50,000 inhabitants & 245 & 15.0 \\
City with 51,000-100,000 inhabitants & 125 & 7.7 \\
City with 101,000-200,000 inhabitants & 122 & 7.5 \\
City with 201,000-500,000 inhabitants & 125 & 7.7 \\
City over 500,000 inhabitants & 185 & \\
Average monthly gross income (per capita in household)* & 11.3 \\
<1,000 zł & 437 & 26.8 \\
1,000-1,999 zł & 363 & 22.2 \\
2,000- 2,999 zł & 219 & 13.4 \\
3,000-3,999 zł & 107 & 6.6 \\
4,000-4,999 zł & 57 & 3.5 \\
5,000-5,999 zł & 81 & 5.0 \\
ב6,000 zł & & \\
\hline
\end{tabular}

* The percentages for average monthly gross income (per capita in household) do not total $100 \%$ due to possible data deficiencies and lack of responses.

Source: own study.

Of those who were physically active, over $70 \%$ engaged in a vigorous physical activity (leading to a highly increased heart rate and breathing). Only one in four respondents performed a moderate physical activity $(24.4 \%)$ or walking (25.5\%). In general, vigorous physical activity, which was declared more often than moderate physical activity or walking, underlay the leisure physical activity amongst Polish males $(69.8 \%)$ and females $(70.7 \%)$.

Interestingly, this mostly affected respondents having a primary education (70.9\%), those employed by the armed forces (75\%), and those who were unemployed (73.2\%). However, it should be mentioned that the differences in this respect were not statistically significant when gender, age, place of residence, gross income, and occupation were taken into consideration.

Walking (whether related to work, involved with shopping, part of getting to work, or leisure walking) was declared by subjects aged 25-39 years (27.6\%). In contrast, subjects aged 15-24 years rarely declared walking as their leisure physical activity (22.8\%). There were industrial laborers and craftsmen on the one side of the spectrum, of which only $18.5 \%$ chose to walk in their leisure time. On the other side were CEOs, administration managers and officials (33.3\%), employees of the armed forces (33.3\%), and professional athletes $(33.3 \%)$. They declared this particular activity more often. However, these differences were not statistically significant. Interestingly, the results show that Polish respondents with primary education declared taking up walking as their physical activity more often than those with higher or secondary education $\left(31.5 \%, 28.1 \%\right.$, and $21.8 \%$, respectively). These differences were found to be significant $\left(\chi^{2}=15.7\right.$, $\mathrm{p}<0.001)$. 
Table 2. The fraction of Polish population aged 15-69 years $(n=1633)$ declaring participation in leisure physical activity

\begin{tabular}{|c|c|c|c|c|}
\hline \multirow[b]{2}{*}{ Variables } & \multicolumn{3}{|c|}{ Leisure PA } & \multirow[b]{2}{*}{ No PA } \\
\hline & $\begin{array}{l}\text { Vigorous } \\
\text { PA }\end{array}$ & $\begin{array}{l}\text { Moderate } \\
\text { PA }\end{array}$ & Walking & \\
\hline \multicolumn{5}{|l|}{ Sex } \\
\hline Male & 69.8 & 26.4 & 25.2 & 21.7 \\
\hline Female & 70.7 & 22.4 & 25.7 & 21.2 \\
\hline \multicolumn{5}{|l|}{ Age } \\
\hline 15-24 years & 71.7 & 24.5 & 22.8 & 22.2 \\
\hline 25-39 years & 68.9 & 25.1 & 27.6 & 23.2 \\
\hline 40-54 years & 72.3 & 25.2 & 23.1 & 18.2 \\
\hline $55-69$ years & 68.7 & 22.4 & 27.3 & 22.1 \\
\hline \multicolumn{5}{|l|}{ Education } \\
\hline Primary & 70.9 & 27.2 & $31.5^{\mathrm{b}}$ & 20.1 \\
\hline Secondary & 70.6 & 23.1 & 21.8 & 22.3 \\
\hline Higher & 68.2 & 24.1 & 28.1 & 20.6 \\
\hline \multicolumn{5}{|l|}{ Place of residence } \\
\hline Village & 70.8 & 23.3 & 24.2 & 21.4 \\
\hline City up to 20,000 inhabitants & 68.9 & 25.0 & 23.6 & 23.9 \\
\hline City with $21,000-50,000$ inhabitants & 71.7 & 23.6 & 23.7 & 20.8 \\
\hline City with 51,000-100,000 inhabitants & 68.7 & 26.6 & 24.7 & 21.6 \\
\hline City with $101,000-200,000$ inhabitants & 72.0 & 25.6 & 35.2 & 17.6 \\
\hline City with $201,000-500,000$ inhabitants & 66.9 & 23.0 & 23.1 & 24.2 \\
\hline City over 500,000 inhabitants & 71.0 & 24.8 & 32.3 & 20.3 \\
\hline \multicolumn{5}{|l|}{ Occupation } \\
\hline CEOs, officials, and administrative managers & 71.7 & 28.3 & 33.3 & 18.3 \\
\hline Professionals and freelancers & 71.3 & 26.3 & 30.9 & 17.7 \\
\hline Technicians and other middle-level staff & 66.2 & 23.0 & 26.9 & 28.8 \\
\hline Office clerks & 69.7 & 27.4 & 23.7 & 19.7 \\
\hline Personal care and sales assistants & 71.3 & 24.0 & 26.8 & 20.7 \\
\hline Farmers, gardeners, foresters, and fishermen & 60.0 & 14.3 & 24.2 & 30.0 \\
\hline Industrial workers and craftsmen & 72.2 & 24.2 & 18.5 & 21.6 \\
\hline Heavy equipment operators and fitters & 71.1 & 28.1 & 27.3 & 19.0 \\
\hline $\begin{array}{l}\text { Support staff (seasonal farmers, cleaners, } \\
\text { security guards) }\end{array}$ & 67.6 & 21.1 & 25.0 & 25.2 \\
\hline Armed forces employees & 75.0 & 30.2 & 33.3 & 16.7 \\
\hline Professional athletes & 50.0 & 33.3 & 33.3 & 16.7 \\
\hline Unemployed & 73.2 & 22.7 & 22.4 & 20.6 \\
\hline \multicolumn{5}{|c|}{ Average monthly gross income (per capita in household) } \\
\hline$<1,000 \mathrm{zł}$ & 67.9 & 20.5 & 23.5 & 23.1 \\
\hline $1,000-1,999 \mathrm{zł}$ & 72.5 & 21.8 & 22.8 & 19.5 \\
\hline $2,000-2,999 \mathrm{zł}$ & 65.2 & 24.9 & 25.2 & 26.6 \\
\hline $3,000-3,999 \mathrm{zł}$ & 73.6 & 23.7 & 30.1 & 18.5 \\
\hline $4,000-4,999 \mathrm{zł}$ & 72.9 & 35.2 & 29.8 & 17.3 \\
\hline $5,000-5,999 \mathrm{zł}$ & 68.4 & 24.6 & 17.5 & 26.3 \\
\hline$\geq 6,000 \mathrm{zł}$ & 75.0 & $38.3^{c}$ & 34.6 & 15.0 \\
\hline Total & $70.2^{\mathrm{a}}$ & 24.4 & 25.5 & 21.5 \\
\hline
\end{tabular}

Statistically significant differences were found for: ${ }^{\text {a }}$ vigorous physical activity vs moderate physical activity and walking $(\mathrm{p}<0.05) ;{ }^{\mathrm{b}}$ primary education vs secondary education $(\mathrm{p}<0.001)$; ${ }^{\mathrm{c}}$ average monthly gross income $\geq 6,000 \mathrm{zł}$ vs all remaining income ranges $(\mathrm{p}<0.01)$.

Source: own study.

Moderate physical activity (leading to a slight increase in breathing and a higher heart rate) was declared significantly more often $\left(\chi^{2}=19.1, \mathrm{p}<0.01\right)$ by those on monthly gross income $\geq 6,000 \mathrm{zł}(38.3 \%)$. The average leisure moderate physical activity among Polish respondents (MET-min/week) was $223 \pm 652.9$ 
and, as with with walking (128.7 \pm 352.4$)$, was relatively lower than the average vigorous physical activity $(1,571.3 \pm 2,394.1)$ (Table 3).

Table 3. Means, standard deviations (SD), and medians of Polish population's leisure physical activity (MET$\mathrm{min} /$ week)

\begin{tabular}{lllllll}
\hline \multirow{2}{*}{ PA } & \multicolumn{2}{l}{ Leisure PA (MET-min./week) } & & \\
\cline { 2 - 7 } & Male & & Female & & Total & \\
& Mean \pm SD & Median & Mean \pm SD & Median & Mean \pm SD & Median \\
\hline Vigorous & $1,474.2 \pm 2,281.4$ & 720.0 & $1,665.2 \pm 2,496.1$ & 960.0 & $1,571.3 \pm 2,394.1$ & 800.0 \\
Moderate & $240.1 \pm 701.2$ & 0 & $206.5 \pm 602.7$ & 0 & $223.0 \pm 652.9$ & 0 \\
Walking & $124.4 \pm 355.0$ & 0 & $132.8 \pm 350.0$ & 0 & $128.7 \pm 352.4$ & 0 \\
\hline
\end{tabular}

Source: own study.

The average leisure physical activity (MET-min/week) was 1,916.9 $\pm 2,621$, with a median of 1,017 (see Table 4). The comparison of current results and European research findings demonstrated that the median physical activity (MET-min/week) for the Polish population was similar to the median of Czech subjects (990 for males and 1,081 for females) (Sigmund et al., 2009) and Norwegian males (Graff-Iversen et al., 2007) and nearly three times higher than Croats over 15 years of age (360) (Jurakić et al., 2009).

Table 4. Means, standard deviations (SD), and medians of Europeans' leisure physical activity MET-min/week

\begin{tabular}{|c|c|c|c|}
\hline \multirow{2}{*}{\multicolumn{2}{|c|}{ Variables }} & \multicolumn{2}{|c|}{ Weekly leisure PA } \\
\hline & & Mean ( \pm SD) & Median \\
\hline \multicolumn{4}{|c|}{ Poland $2012(n=1,633 ;$ aged $15-69)$} \\
\hline Male & & $1,816.6(2528.6)$ & 960.0 \\
\hline Female & & $2,013.5(2705.1)$ & $1,065.0$ \\
\hline Total & & $1,916.9(2621.0)$ & $1,017.0$ \\
\hline \multicolumn{4}{|c|}{ Greece $2004(n=300 ;$ aged 20-50) } \\
\hline \multirow{4}{*}{ Male } & 20-29 years & $216.4(240.6)$ & \\
\hline & 30-39 years & $74.1(148.1)$ & \\
\hline & 40-50 years & $113.0(137.0)$ & \\
\hline & 20-29 years & $228.0(257.6)$ & \\
\hline \multirow[t]{2}{*}{ Female } & 30-39 years & $132.0(126.2)$ & \\
\hline & $40-50$ years & $136.2(153.6)$ & \\
\hline \multicolumn{4}{|c|}{ Norway $2000(n=2,274 ; 31-67$ years old $)$} \\
\hline \multirow{2}{*}{ Male } & $\geq 12$ years of education & & 1,230 \\
\hline & $<12$ years of education & & 891 \\
\hline \multirow{2}{*}{ Female } & $\geq 12$ years of education & & 1,389 \\
\hline & $<12$ years of education & & 1,024 \\
\hline \multicolumn{4}{|c|}{ Croatia $2007(n=1,032 ;>15$ years old $)$} \\
\hline Male & & & 360 \\
\hline Female & & & 360 \\
\hline Total & & & 360 \\
\hline \multicolumn{4}{|c|}{ Czech Republic 2004-2005 ( $\mathrm{n}=3,377)$} \\
\hline Male & & & 990 \\
\hline Female & & & 1,081 \\
\hline \multicolumn{4}{|c|}{ Sweden $2002-2005(n=704 ; 18-65$ years old $)$} \\
\hline Female & & & 714 \\
\hline \multicolumn{4}{|c|}{ Finland $2002-2005(n=865 ; 18-65$ years old $)$} \\
\hline Female & & & 792 \\
\hline
\end{tabular}


Similarly, the average leisure physical activity of Polish respondents (MET-min/week) aged 20-50

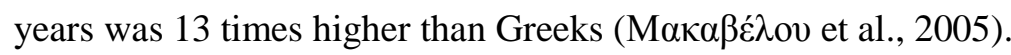

The median of all physical activities undertaken by Polish females (MET-min/week) was lower $(1,065)$ than the median of educated Norwegian females (over 12 years of education, 1,389) (Graff-Iversen et al., 2007) but much higher than Swedish females (714) or Finns (792) (Södergren et al., 2010).

A similar pattern was observed for males: the median for Polish males was 960, whereas Norwegians with more than 12 years of education had a median of 1,230 and those with less than 12 years of education 891 (Graff-Iversen et al., 2007).

\section{Discussion}

Increasing the amount of physical activity undertaken by European citizens is challenging for the public health sector across the EU. Promoting a healthy lifestyle requires effective strategies that encourage participation in various forms of physical activity. Furthermore, there is a need for continuous monitoring and analysis of this phenomenon.

The current investigation regarding the Polish population shows that close attention should be given to specific occupational groups (i.e., farmers, gardeners, foresters, and fishermen) that show a very low level of leisure physical activity (30\%). Polish respondents with gross income in the range of 2,000-2,999 $\mathrm{zl}$ and those educated to the secondary level show a similar percentage of physical activity $(26.6 \%$ and $22.3 \%$, respectively). This is consistent with the fact that leisure physical activity is rarely undertaken by those who do physical work (Salmon et al., 2000; Marquez et al., 2010) or those educated to the lower level (Jones et al., 1998) and with lower income (Burton \& Turrel, 2000).

Given that the lack of physical activity (sedentary lifestyle) is one of the main factors putting people at a higher risk for developing cardiovascular disease and other chronic disorders, it is necessary to educate the most inactive population groups by stressing the importance of active, healthy lifestyles. These groups should be made aware of the need for physical activity in their leisure time as well as the intensity levels at which these activities should be performed. The intensity of a physical activity affects physiological outcome of that activity and is crucial for health and safety. It is suggested to undertake a moderate physical activity ( $\geq 150 \mathrm{~min} /$ week) (Drygas \& Jegier, 2009) with the possibility of replacing it with a vigorous activity ( $\geq 75 \mathrm{~min} /$ week) or a combination of a moderate and vigorous activity (WHO, 2010). It should be pointed out that among Polish respondents who declared leisure physical activity, over $70 \%$ stated that they were engaged in a vigorous physical activity; only one in four declared moderate physical activity (24.4\%) or walking (25.5\%). Additionally, no significant differences were found in this respect when the age of subjects was taken into consideration. This might be due to limited knowledge of the training methods of the subjects or that the findings were affected by issues with the IPAQ's use in Poland (for example, misunderstanding the term "intensity"). It supports the statement put forward by the authors of Polish version of IPAQ: the practice of respondents completing the surveys (and CATI) independently may result in errors (such as overestimation of energy expenditure) (Biernat et al., 2008).

As current findings show, a relatively high percentage (nearly $80 \%$ ) of active Polish population is striking when compared with British (43.85\%, aged 35.3 \pm 10.4 years) or Dutch $(48.5 \%$, aged $32.7 \pm 10.9$ years) (Rosenberg et al., 2008). This is even more shocking, considering that British and Dutch are perceived as very active nations. Perhaps these highly positive results are biased towards young people (the age range of Polish subjects was 15-69 years of age). It would be incorrect to assume that such a high proportion of active Polish people is due to misunderstanding the survey's questions.

However, research shows that the average and median leisure physical activity of Polish respondents (MET-min/week) is comparable with the results of other European citizens. The median value (MET$\mathrm{min} /$ week) for Polish males and females (960 and 1,065, respectively), for instance, were nearly the same as Czech males and females (990 and 1,081, respectively) and only slightly lower than the medians of 
Norwegians educated to a degree level (1,230 for males and 1,389 for females with over 12 years of education and 891 for males and 1,024 for females with less than 12 years of education) (Graff-Iversen et al., 2007). It is not surprising that the Polish population is characterized by lower levels of leisure physical activity than the Scandinavian population. According to Martinez-Gonzalez et al. (2001), northern Europeans are considered to be much more physically active than those people living in southern Europe. In light of these findings, it should not come as a surprise that the average leisure physical activity (MET-min/week) of

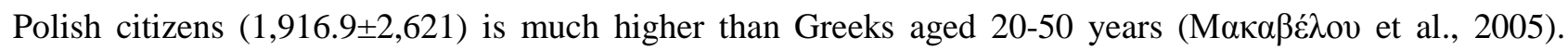
Similarly, the median in Poland is 1,017 , which is higher than the median of Croats above 15 years of age (360) (Jurakić et al., 2009). However, it is puzzling that the median leisure physical activity for Polish females (MET-min/week) is higher than Swedish (714) or Finns (792) (Södergren et al., 2010). This may be a result of the majority of Polish women (70.7\%) declaring vigorous leisure physical activity, which in turn may have influenced the overall energy expenditure score.

The detailed analysis of individual types of physical activity shows that the average leisure walking MET-min/week for Polish respondents is much lower (128.7 \pm 352.4 , of which the average for males was $124.4 \pm 355$ and females $132.8 \pm 350)$ than Czech respondents $(1,727.5$, of which the average for males was 1,692 and females 1,763) (Sigmund et al., 2009). The Polish respondents' median equals zero, meaning that at least half of the subjects walk no more than 10 minutes in general, whereas Swedish people aged 20-65 years walk 60 minutes per day (198 MET-min/week) (Sundquist et al., 2011) and Norwegian men (depending on the level of education): 2,520 (12 years of education or more) and 3,323 MET-min/week (less than 12 years of education) (Graff-Iversen et al., 2007). Depending on level of education, the median walking for Norwegian women (MET-min/week) was 3,450 and 3,561, respectively.

The Polish respondents' average moderate leisure physical activity (MET-min/week) is close to that of Belgians aged 20-65 years (Van Dyck et al., 2011). It is $223 \pm 652.9$ for the Polish population and 36.1 \pm 95.9 minutes per day for a Belgian group (144.4 MET-min/week). When considering Europe's younger population, there is a difference between south and north of the continent: Polish respondents aged 25-39 years undertake more physical activities of moderate intensity (196.4 \pm 509.3 MET-min/week) compared to Portuguese of the same age (31 \pm 84 MET-min/day, which gives 124 MET-min/week) but less when compared with the same age group in Belgium (64 \pm 132 MET-min/day, which gives roughly 256 MET$\mathrm{min} /$ week) (De Bourdeaudhuij et al., 2005).

The largest discrepancy was observed in vigorous physical activity: the average value for Polish subjects was 1,571.3 $\pm 2,394.1$ MET-min/week (1,474.2 $\pm 2,281.4$ for males and 1,665.2 $\pm 2,496.1$ for females),

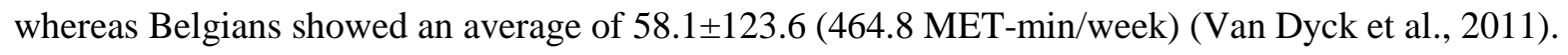

\section{Conclusions}

1. Insufficient participation in the conscious process of caring for one's own health is a common occurrence amongst adults living in the EU. Sadly, this problem particularly challenges individuals who work physically, have lower levels of education, and a lower gross income. In Poland, these are mainly farmers, gardeners, foresters, and fishermen. Additionally, this group consists of people with monthly gross income of 2,000-2,999 zł and those educated to a secondary school level.

2. In order to encourage the Polish population to participate in physical activities, it is necessary to raise their awareness of a need of well-balanced, regular exercise. Knowledge of the intensity levels of undertaken physical activity should be an integral part of our healthy lifestyle.

3. The outcome of the current study shows that using CATI (Computer-Assisted Telephone Interview) is not error free. Exclusion of 132 participants who declared over 16 hours of physical activity per day is one of the difficulties encountered when using this questionnaire. As telephone surveys in Poland are neither particularly popular yet nor widely used, there are issues with delivering a questionnaire this way. First, the respondents are easily disheartened because the interview process is fairly long. Second, they often lack a full understanding of the content of the questionnaire, which may lead to 
overestimations or underestimations. It appears that delivering surveys via phone requires much stricter and controlled training of the staff in terms of face-to-face technique, explaining questions, and consistency in asking the questions.

\section{Acknowledgement}

The project was funded by the Ministry of Sport and Tourism of the Republic of Poland.

\section{REFERENCES}

Biernat, E. (2011). Aktywność fizyczna mieszkańców Warszawy na przykładzie wybranych grup zawodowych /Physical activity of Warsaw's population, based on selected occupational groups/. Warszawa: Szkoła Główna Handlowa, Urząd m. st. Warszawy. Biuro Sportu i Rekreacji.

Biernat, E. (2013). International Physical Activity Questionnaire - Polish long version. Polish Journal of Sports Medicine, 29(1), 1-15.

Biernat, E., Stupnicki, R., Gajewski, A.K. (2007). Międzynarodowy Kwestionariusz Aktywności Fizycznej (IPAQ) wersja polska. Phys Educ Sport, 51(1), 47-54.

Biernat, E., Stupnicki, R., Lebiedziński, B., Janczewska, L. (2008). Assessment of physical activity by IPAQ questionnaire. Physical Education and Sport, 52(2), 83-89.

Burton, N.W., Turrel, B. (2000). Occupation, hours worked, and leisure time physical activity. Prev Med., 3, 673-81.

De Bourdeaudhuij, I., Teixeira, P.J., Cardon, G. Deforche, B. (2005). Environmental and psychosocial correlates of physical activity in Portuguese and Belgian adults. Public Health Nutrition, 8(07), 886-895.

Drygas, W., Jegier, A., Bednarek-Gejo, A., Kostka, T. (2005). Long-term effects of various physical activity levels in preventing obesity and metabolic syndrome in middle-aged men. Eur J Cardiovasc Prev Rehab, 12, 283.

Gajewski, A.K., Biernat, E. (2010). Zastosowanie Międzynarodowego Kwestionariusza Aktywności Fizycznej (IPAQ) - za i przeciw, czyli kilka rozważań metodycznych i ich konsekwencje/Pros and cons of the International Physical Activity Questionnaire (IPAQ) use: Methodical issues and their implications/. In K. Buśko, J. Charzewska, K. Kaczanowski (Eds.), Wspótczesne metody badań aktywności, sprawności i wydolności fizycznej cztowieka /Current methods of investigating physical activity, fitness and endurancel. Warszawa: AWF Warszawa.

Graff-Iversen, S., Anderssen, S.A., Holme, I.M., Jenum, A.K., Raastad, T. (2007). An adapted version of the long International Physical Activity Questionnaire (IPAQ-L): construct validity in a low-income, multiethnic population study from Oslo, Norway. International Journal of Behavioral Nutrition and Physical Activity, 4, 13.

Jones, D.A., Ainsworth, B.E., Croft, J.B., Macera, C.A., Lloyd, E.E., Yusuf, H.R. (1998). Moderate Leisure-Time Physical Activity. Arch Fam Med, 7(3), 285-289.

Jurakić, D.,Pedišić, Ž,., Andrijašević M. (2009). Physical Activity of Croatian Population: Cross-sectional Study Using International Physical Activity Questionnaire. Croatian Medical Journal, 50(2), 165-173.

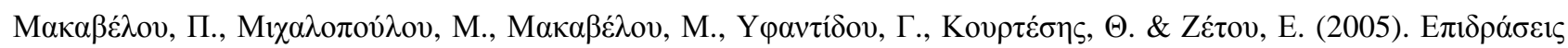

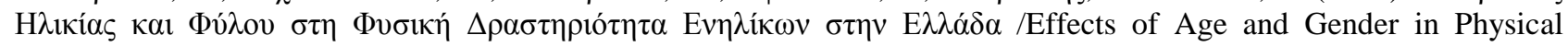
Activity of Adults in Greece/. Inquiries in Sport \& Physical Education, 3(2), 176-186.

Marquez, D.X., Neighbors, C.J., Bustamante, E.E. (2010). Leisure time and occupational physical activity among racial or ethnic minorities. Med Sci Sports Exerc, 42, 1086-93.

Martinez-Gonzalez, M.A., Varo, J.J., Santos, J.L., De Irala, J., Gibney, M., Kearney, J., Martinez, J.A. (2001). Prevalence of physical activity during leisure time in the European Union. Med Sci Sports Exerc, 33, 1142-6.

Piątkowska, M. (2012). Self-rated physical activity across Europe - Poland and other European countries. Biol Sport, 29(1), 23-31. DOI: 10.5604/20831862.979848.

Rosenberg, D.E., Bull, F.C., Marshall, A.L., Sallis, J.F., Bauman, A.E. (2008). Assessment of Sedentary Behavior With the International Physical Activity Questionnaire. Journal of Physical Activity \& Health, 5(supp 1), 30-44.

Salmon, J., Owen, N., Bauman, A., Schmitz, M.K., Booth, M. (2000). Leisure time, occupational, and household physical activity among professional, skilled, and less-skilled workers and homemakers. Prev Med, 30, 191-199.

Sidney, S., Jacobs, Jr. D.R., Haskell, W.L., Armstrong, M.A., Dimicco, A., Oberman, A., Savage, P.J., Slattery, M.L., Sternfeld, B., Van Horn, L. (1991). Comparison of two methods of assessing physical activity in coronary artery risk development in young adults (CARDIA) study. American Journal of Epidemiology, 133, 1231-1245.

Sigmund, E., Sigmundová, D., Mitáš, J., Chmelík, F., Vašíčková, J., Frömel, K. (2009). Variability of selected indicators of physical activity in a randomized sample of the Czech population between the years 2003-2006: results 
from the short and long self-administered format of the IPAQ questionnaire. Acta Univ. Palacki. Olomuc. Gymn., 39(2), 23-31.

Södergren, M., Sundquist, K., Johansson, S.E.,Sundquist, J., Hagströmer, M. (2010). Associations Between HealthEnhancing Physical Activity and Country of Birth Among Women. Journal of Physical Activity \& Health, 7(5), 613621.

Sundquist, K., Eriksson, U., Kawakami, N., Skog, L., Ohlsson, H., Arvidsson, D. (2011). Neighborhood walkability, physical activity, and walking behavior: The Swedish Neighborhood and Physical Activity (SNAP) study, Social Science \& Medicine, 72, 1266-1273.

Toczek-Werner, S., Sołtysik, M. (1997). Aktualny stan badań nad czasem wolnym mieszkańców dużych miast polskich /The current state of research on leisure time of residents in large Polish cities /. In J. Wyrzykowski (Ed.), Koncepcja badań nad czasem wolnym mieszkańców Wrocławia i jego wykorzystaniem na rekreację $i$ turystykę. Materiaty seminaryjne /The research protocol on Wroctaw's population's leisure time and the use of Wroctaw's recreation and tourist potential. Seminar material/. Wrocław: AWF.

Van Dyck, D., Cardon, G., Deforche, B., Giles-Corti, B., Sallis, J.F. Owen, N., De Bourdeaudhuij, I. (2011). Environmental and Psychosocial Correlates of Accelerometer-Assessed and Self-Reported Physical Activity in Belgian Adults. Int. J. Behav. Med., 18, 235-245.

\section{Internet sources:}

Drygas, W., Jegier, A. (2009). Zalecenia dotyczace aktywności ruchowej w profilaktyce chorób układu krążenia /Physical activity recommendations for cardiovascular disease prevention/. Retrieved 22.12 .2012 from http://www.umed.lodz.pl/geriatria/pdf/Zalecenia_dotyczace_aktywnosci_ruchowej_w_profilaktyce_chorob_ukladu_kra zenia.pdf

European Commission (2004). Special Eurobarometer 213/62.0. The citizens of the European Union and Sport. Retrieved 22.12.2012 from http://ec.europa.eu/public_opinion/archives/ebs/ebs_213_summ_en.pdf

European Commission (2010). Special Eurobarometer 334/72.3. Sport and Physical Activity. Retrieved 22.12.2012 from http://ec.europa.eu/public_opinion/archives/ebs/ebs_334_en.pdf

Guidelines for Data Processing and Analysis of the International Physical Activity Questionnaire (IPAQ) - Short and Long Forms (2005). Retrieved 22.12.2012 from www.ipaq.ki.se

International Physical Activity Questionnaire. Retrieved 22.12.2012 from www.ipaq.ki.se

O aktywności fizycznej Polaków. Komunikat z badań /Polish population physical activity. Research broadcast/(2003). Warszawa: CBOS. Retrieved 22.12.2012 http://www.cbos.pl/SPISKOM.POL/2003/K_023_03.PDF

Physical Activity and Health: a Report of the Surgeon General. (1996). Atlanta, Georgia: US Department of Health and Human Services; Retrieved 22.12.2012 from http://www.cdc.gov/nccdphp/sgr/pdf/execsumm.pdf

The European Social Survey. Retrieved 22.12.2012 from www.ess.nsd.uib.no

WHO (2010) Global Recommendations on Physical activity for Health. Retrieved 22.12 .2012 from http://whqlibdoc.who.int/publications/2010/ 9789241599979_eng.pdf

AUTHOR'S ADDRESS: $\quad$ Elżbieta Biernat

SGH, CWFiS Al. Niepodległości 162

02-554 Warszawa

Poland

Email: elzbieta.biernat@sgh.waw.pl 